\title{
Mill's Evolutionary Theory of Justice: Reflections on Persky
}

\author{
Piers Norris Turner* (D) \\ Ohio State University \\ ${ }^{*}$ Corresponding author. Email: turner.894@osu.edu
}

\begin{abstract}
Joseph Persky's excellent book, The Political Economy of Progress: John Stuart Mill and Modern Radicalism, shows that J. S. Mill's support for socialism is a carefully considered element of his political and economic reform agenda. The key thought underlying Persky's argument is that Mill has an 'evolutionary theory of justice', according to which the set of institutions and practices that are appropriate to one state of society should give way to a new set of institutions as circumstances change and the people themselves improve. However, Persky does not spend a great deal of time discussing Mill's theory of reform, in particular the principles he believes should guide our reform efforts. Reflecting on these principles - notably his principle of impartiality or equal treatment - shows the consistency of Mill's thought over time.
\end{abstract}

\section{Introduction}

The interpretation of J. S. Mill's political philosophy has been shaped by two main challenges. The first is to explain the relationship between his utilitarianism and his support for a robust system of liberal rights. (Can a thoroughgoing utilitarian really be a 'principled' liberal?) The second is to explain the relationship between his support for a robust system of liberal rights and his qualified advocacy of socialism. (Isn't socialism a threat to liberal rights?) Any attempt to make sense of Mill's synthesis of welfare, liberty, and equality will need to face both of these challenges squarely.

Unfortunately, they have not always been faced squarely by Mill scholars, much to the detriment of the common understanding of his views. My complaint is not against interpreters who disagree about how best to combine the various elements of Mill's political philosophy, but against commentators who dismiss or explain away one or more of those elements rather than work to fit them together. The most common example of this is found in those who, having read On Liberty, do not grapple fairly with Mill's other core commitments that might seem to threaten his status as a champion of individuality. The author of On Liberty, they say, could not also be a thoroughgoing utilitarian or a socialist.

Isaiah Berlin, for instance, argues that the true spirit of Mill is contained in On Liberty's arguments for individuality and diversity and, therefore, that his continued espousal of utilitarianism must be due to the irrational influence of his father - against whom the younger Mill was engaged in 'unceasing revolt', though 'subterranean and 
unacknowledged'. ${ }^{1}$ Berlin then attributes Mill's support for socialism to the undue influence of his wife, Harriet Taylor; his support for socialism being otherwise 'peculiar', given that he was 'preoccupied with the ... evils of socialisation and uniformity'. One might start to wonder how Mill, famously raised to be a rational thinking machine, could defend what Berlin regards as such an obviously inconsistent set of views. But Berlin assures us: 'Rigour in argument is not among [Mill's] accomplishments'? ${ }^{3}$ Mill is rather a wonder of self-denial and confusion. As a result, Berlin neither grounds Mill's support for liberal rights in his utilitarianism, nor tries to show how individuality might be consistent with the forms of socialism Mill defends. With such a one-sided reading, we have no systematic grasp of Mill's overall picture.

Happily, we can also point to serious attempts by Mill scholars to synthesize these elements. One excellent recent example, focusing on Mill's radical egalitarian proposals, is Joseph Persky's engaging book The Political Economy of Progress: John Stuart Mill and Modern Radicalism. ${ }^{4}$ Persky shows that Mill's support for socialism is not to be explained away as some temporary blip or inconsistent part of his picture; it is a carefully considered element of his political and economic reform agenda. In doing so, Persky also reinforces other important work on Mill's socialism. ${ }^{5}$ Collectively, these scholars have shown that any fair interpretation of Mill's political philosophy must systematically account for his conviction that society, including its economic system, should ultimately be transformed in a thoroughly egalitarian direction. Toward this end, Mill proposes not only equal social and political rights for women and racial and religious minorities, but also public education, subsistence programs, heavy inheritance taxes to redistribute wealth, limits on property rights (especially ownership of land), and economic democracy in the form of worker cooperatives. Properly understood, none of this is inconsistent with individual liberty.

Part of what is striking about Persky's book is that it is pitched to those on the radical left - perhaps because Mill is there commonly viewed much as Berlin sees him, as a sort of proto-libertarian and godfather of neoliberalism. ${ }^{6}$ In a very helpful chapter on Marx and Mill, Persky argues that this view on the left is at least partly due to Marx's own unwillingness to acknowledge his affinities with Mill's criticisms of

\footnotetext{
${ }^{1}$ Isaiah Berlin, 'John Stuart Mill and the Ends of Life', Liberty, ed. Henry Hardy (Oxford, 2002), pp. 218-51, at 227.

${ }^{2}$ Berlin, 'John Stuart Mill and the Ends of Life', p. 228 n. 3 and associated text.

${ }^{3}$ Berlin, 'John Stuart Mill and the Ends of Life', p. 234.

${ }^{4}$ Joseph Persky, The Political Economy of Progress: John Stuart Mill and Modern Radicalism (Oxford, 2016).

${ }^{5}$ Perhaps the single most instructive article on Mill's socialism is Helen McCabe, 'Navigating by the North Star: The Role of the "Ideal" in John Stuart Mill's View of "Utopian" Schemes and the Possibilities of Social Transformation', Utilitas 31 (2019), pp. 291-309. See also: Bruce Baum, 'J. S. Mill and Liberal Socialism', J. S. Mill's Political Thought: A Bicentennial Reassessment, ed. Nadia Urbinati and Alex Zakaras (Cambridge, 2007), pp. 98-123; Gregory Claeys, Mill and Paternalism (Cambridge, 2013); Samuel Hollander, John Stuart Mill: Political Economist (Toronto, 2015); Oskar Kurer, John Stuart Mill: The Politics of Progress (New York, 2016); Dale E. Miller, 'Mill's "Socialism"', Politics, Philosophy, \& Economics 2 (2003), pp. 213-38; Jonathan Riley, 'J. S. Mill's Liberal Utilitarian Assessment of Capitalism Versus Socialism', Utilitas 8 (1996), pp. 39-71.

${ }^{6}$ Interestingly, some libertarians such as Hayek noticed (and deeply lamented) the fact that Mill was not in the end a fellow-traveler. Like Berlin, however, Hayek saw Mill's eventual support for socialism as the influence of Harriet Taylor, and this perhaps explains why Mill is still commonly lauded in public debates for his defence of individual liberty, without being similarly praised as a crusader for social equality and distributive justice. See Hollander, John Stuart Mill, ch. 11 for discussion of Hayek's view of Mill.
} 
Victorian-era capitalism. (Mill's involvement with the East India Company, which Persky mentions but does not focus on, also invites suspicion. ${ }^{7}$ ) Persky's main claim is that radicals on the left - those looking to transform our social, political, and economic institutions so that 'meaningful paths to self-definition and participation are available to all, including the least advantaged' - should look to Mill for guidance. ${ }^{8}$ On Persky's account, Mill 'identifies for the first time the key components of modern radicalism: an analytical approach based on political economy, the progressive power of market-driven accumulation, the ultimate emergence of an abundant economy, and the need for radical institutional change'.

The key thought underlying Persky's argument is that Mill has an 'evolutionary theory of justice', according to which the set of institutions and practices that are appropriate to one state of society should give way to a new set of institutions as circumstances change and the people themselves improve. ${ }^{10}$ This is not an entirely new idea in the literature mentioned earlier, but Persky - who is an economist makes a powerful case that laissez-faire capitalism is for Mill only a 'transitional mode of production' allowing for capital accumulation that eventually should give way to a more cooperative and democratic economic system in a stationary state. ${ }^{11}$ In this way, Persky shows that Mill's radical economic proposals - such as his support for a system of worker cooperatives - can be reconciled with his 'broad endorsement of laissez-faire capitalism'. ${ }^{12}$ Through enlightening discussions of a wide range of Mill's influences in political economy and a sensitive reading of an equally wide range of Mill's writings, Persky paints a convincing picture of the substantive changes Mill hopes will result from the evolutionary reform process.

The main aim of the present article is to explore the value of coming to understand Mill's evolutionary theory of justice. Despite the importance of the evolutionary idea to his overall argument, Persky does not spend a great deal of time discussing either Mill's account of the process of social and political evolution - such as his deep commitment to free discussion in civilized society - or the public principles that Mill believes should guide our reform efforts (short of the principle of utility itself). In this article, I focus on the second issue in particular. Persky's most sustained discussion of it appears in the final chapter, 'Radical Luck', where he uses the debate between luck egalitarians and relational egalitarians to argue that Mill's egalitarianism drives his progressive efforts. Although I agree that Mill's egalitarianism is central to the evolutionary story, I believe there is more to say about the specific structure of Mill's approach.

I also argue that only with a more developed account can we evaluate what reforms Mill might have endorsed today, and what tradeoffs he might have been willing to make

\footnotetext{
${ }^{7}$ For an informed and careful assessment of Mill's tenure in the East India Company, see Georgios Varouxakis, Liberty Abroad: J. S. Mill on International Relations (Cambridge, 2013), ch. 5. For background, see Martin Moir, 'Introduction', in John Stuart Mill, Writings on India, CW XXX, pp. vii-liv. Citations of Mill marked by 'CW volume number, page number' refer to the Collected Works of John Stuart Mill, ed. J. M. Robson, 323 vols (Toronto, 1963-91).

${ }^{8}$ Persky, Political Economy of Progress, p. xiii. Persky suggests that in recent decades radicals have not done well in articulating a clear path forward. Erik Olin Wright's influential Envisioning Real Utopias (London, 2010) might be a counterexample. Interestingly, despite echoing many aspects of Mill's reform programme, Wright does not mention Mill in that book.

${ }^{9}$ Persky, Political Economy of Progress, p. 88.

${ }^{10}$ Persky, Political Economy of Progress, p. xvi.

${ }^{11}$ Persky, Political Economy of Progress, pp. 151, 76.

${ }^{12}$ Persky, Political Economy of Progress, p. xvii.
} 
among his various commitments. Persky, for his part, is reticent to speculate beyond those reforms Mill explicitly proposed. For all the discussion in the literature of whether Mill's vision of worker cooperatives really constitutes a form of socialism (I believe it does), what truly matters are the reasons he offers for various reforms, and whether his reasons would lead in a more socialist direction. As Persky recognizes, these reasons are not captured simply by a direct appeal to the principle of utility. Mill tells us: 'I do not mean to assert that the promotion of happiness should be itself the end of all actions, or even of all rules of action. It is the justification, and ought to be the controller, of all ends, but is not itself the sole end. ${ }^{, 13}$ My aim, then, is to help advance our understanding of Mill's principles of reform: those publicly accessible principles that Mill believes should guide the revision of our standards of justice as we move from one state of society to the next.

In our American political moment, I believe all liberals would benefit from reading Persky's study of Mill - not just the left radicals to whom the book is primarily addressed. What liberals face today is in some ways not so different from the set of alternatives Mill articulated in the late nineteenth century. On one hand, there were Victorian-era defenders of the laissez-faire system, the forerunners of today's neoliberals who were criticized in very similar terms. They had come to be defenders of an entrenched status quo, believers in a system of private property and competition that, for all its economic benefits, had left many people insecure and with few real opportunities for self-determination (but a great deal of drudgery), and was therefore unable to answer to higher democratic ideals. ${ }^{14}$ On the other hand, there were what Mill called 'revolutionary socialists' - among whom Marx would later become the most important - who had near-term hopes of a wholesale overthrow of existing political and economic institutions. Mill worried that these revolutionaries, like some today, recklessly threatened social stability for the uncertain promise of comprehensive change. In the middle somewhere was Mill himself, arguing for a series of radical, but feasible, reforms that would retain the benefits of competition and individual liberty while taking significant steps toward social and economic equality. Over time, he thought, we could arrive at a system that would 'unite the greatest individual liberty of action, with a common ownership in the raw material of the globe, and an equal participation of all in the benefits of combined labour'. ${ }^{15}$ Persky provides an excellent guide to many of the central issues in that debate, and makes a convincing case for the reformist but ultimately radical Millian approach. My aim is to further his argument by beginning to develop the principles that underlie Mill's reform efforts.

\footnotetext{
${ }^{13}$ Mill, System of Logic, CW VIII, p. 952.

${ }^{14}$ It is impossible to summarize succinctly the debates associated with the term 'neoliberalism'. But when 'neoliberal' is used as an epithet, it seems to me that there are two key complaints. First, there is the complaint that free markets in many cases serve to protect entrenched interests and the status quo. Free markets sometimes help to level the playing field, but in the real world they also sometimes serve to enshrine power, which is often the result of historical injustice. Second, there is the complaint that free market values should not dominate all other public or social values. The basic worry here is that the diffusion of market ideology into all walks of life has pernicious effects on people's character and well-being. Too many people come to see life as a competition, in which other individuals or groups are trying to 'cut in line' or take what is theirs; too many people see success or self-worth, and the value of education, in primarily monetary terms; too many people accept the myth of rugged individualism. In all of this, there is a corresponding decline in social trust, in our appreciation of the intrinsic value of education, and in our recognition of the ways social, political, and economic institutions create opportunities and support us in our endeavours.

${ }^{15}$ Mill, Autobiography, CW I, p. 239.
} 


\section{Does it matter whether Mill was a socialist?}

Much of the discussion of Mill's socialism starts from the claim in his Autobiography that the 'ideal of ultimate improvement' he shared with Harriet Taylor 'went far beyond Democracy, and would class us decidedly under the general description of Socialists' ${ }^{16}$ The natural question, then, is what this ideal consists in. Persky and others have carefully excavated Mill's key proposals for political economic reform and ultimately - to borrow Perky's phrase - 'full-scale transformation of the productive economy'. ${ }^{17}$ This transformation does not embrace every positive proposal of the socialists - in fact, Mill is very skeptical about central planning, remains committed to the value of competition (at least in some respects), and worries that 'communism', a strong form of socialism, might be incompatible with individual liberty. But he endorses a series of radically redistributive proposals with regard to taxation and land reform, subsistence aid, and a system of worker cooperatives that would eliminate the wage relationship between capital and labor, thereby bringing democracy into the workplace.

Mill is very interested in the ways many key egalitarian reforms could be made consistent with commitments to markets, strong property rights, and competition to form what Jonathan Riley calls a 'capitalist liberal utopia'. But, as Riley also observes, this 'capitalism in its best form' would itself constitute a radical shift and 'hardly resemble familiar capitalist arrangements'. ${ }^{18}$ The powerful equalizing effect of Mill's proposals for the distribution of wealth, opportunities, and political influence, his willingness to place serious conditions on property rights (such as allowing the state to tax landowners on increases in rents due to social or natural causes), and the well-established socialist pedigree of worker cooperatives, to my mind place Mill in the socialist camp. These cooperatives, he argues, 'would be the nearest approach to social justice, and the most beneficial ordering of industrial affairs for the universal good, which it is possible at present to foresee', assuming, in addition, that women had full equal rights. ${ }^{19}$ One could narrow the meaning of 'socialism' to require central planning and the elimination of private property - some still seem to use the term that way - but modern socialism requires neither of those.

In an insightful paper, Dale E. Miller has argued that because, on Mill's view, the shift to worker cooperatives as profit rates fall is meant to happen spontaneously and voluntarily, involving no coercive taking of property from capitalists, classical liberals should not object to these shifts. ${ }^{20}$ Persky also has a very instructive discussion of how Mill believes capitalism might transition to a stationary state of its own accord, but I think it is important not to rely too much on the spontaneity claim. ${ }^{21}$ Mill allows government to take proactive steps to develop citizens for further stages of improvement, and he clearly believes society ought to move toward greater equality, sympathy, and social harmony. Although Mill rejects revolutionary change in England, Persky notes that he does 'look forward to a progress built on economic growth, social development, and interventions made possible by the effective application of social science. ${ }^{22}$ In Considerations on Representative Government and elsewhere, Mill argues that

\footnotetext{
${ }^{16}$ Mill, Autobiography, CW I, p. 239.

${ }^{17}$ Persky, Political Economy of Progress, p. 25.

${ }^{18}$ Riley, 'J. S. Mill's Liberal Utilitarian Assessment of Capitalism versus Socialism', p. 64.

${ }^{19}$ Mill, Principles of Political Economy, CW III, p. 794.

${ }^{20}$ Miller, 'Mill's “Socialism”', pp. 213-38.

${ }^{21}$ Persky, Political Economy of Progress, pp. 81-3.

${ }^{22}$ Persky, Political Economy of Progress, p. 25, emphasis added.
} 
government plays a key role in bringing about the development of the people themselves in every state of society:

In all states of human improvement ever yet attained, the nature and degree of authority exercised over individuals, the distribution of power, and the conditions of command and obedience, are the most powerful of the influences, except their religious belief, which make them what they are, and enable them to become what they can be. ${ }^{23}$

Mill writes extensively about the proper design of representative democracy to encourage personal development among citizens, defends the role of a tax-funded government to act non-coercively in ways that would foster individual development, and frankly supports using the coercive power of government to promote social equality by extending the franchise, establishing women's rights, outlawing primogeniture, placing heavy taxes on inheritance, improving working conditions, providing subsistence aid, and other measures. It is also true that in 'civilized' society he is wary of government coercion, believes individuals are generally the best judges of their own good, accepts the great value of markets and commerce for developing cooperative society in the first place, and works to preserve the conditions needed for individuality and 'experiments of living, ${ }^{24}$ But he does not just rely on spontaneous processes in pursuing utilitarian ends, and I don't see why we should constrain his view when it comes to taking steps toward worker cooperatives or other socialist proposals - as long as they remain consistent with civil and political liberty.

I cannot hope to add much to Persky's discussion of Mill's particular proposals and their fit within the radical and socialist traditions, but I would like to make two points not emphasized sufficiently to my mind. The first is that even if Mill's fully formed statements about socialism do not emerge until 1851 with the publication of 'Newman's Political Economy'25 (and, the following year, with the third edition of Principles of Political Economy), some of the central arguments that led him in that direction were visible even in very early writings. ${ }^{26}$ Even Persky dates Mill's 'ambivalence' toward traditional liberalism and laissez-faire capitalism to the 'mid-nineteenth century', but key ideas came on board much before that. As Miller has noted, a powerful statement of Mill's commitment to greater wealth equality is expressed in a debating speech from 1828, when Mill is in his early twenties, before he met Harriet Taylor. ${ }^{27}$ There he writes: 'I have satisfied myself that equal distribution, failing special reasons

\footnotetext{
${ }^{23}$ Mill, Considerations on Representative Government, CW XIX, p. 394; see also p. 390, and CW I, p. 177.

${ }^{24}$ Mill, On Liberty, CW XVIII, p. 261.

${ }^{25}$ Mill, $C W$ V, pp. 441-57.

${ }^{26}$ As already mentioned, there is an over-excited tendency among commentators to attribute Mill's prosocialist writings to his being 'henpecked' by Harriet Taylor (for discussion, see Claeys, Mill and Paternalism, p. 40). Of course, Mill himself credits Taylor with co-authorship of the additions to Principles of Political Economy, and she deserves credit for her contributions. But the young Mill was already articulating principles that would lead towards socialism, and his Chapters on Socialism, written years after Taylor had passed away, repeats his support for some core socialist claims (while also emphasizing his concerns about some others). Mill also retained their additions to Principles of Political Economy through successive editions up to his own death.

${ }^{27}$ Persky writes: 'There can be no doubt that John Stuart Mill in the 1820 s and early 1830 s largely limited his advocacy of reform to little more than an expansion of the franchise coupled to free markets' (Political Economy of Progress, p. 21). But, to take two just examples, his support for birth control measures (he was
} 
to the contrary, is the one arrangement dictated by a regard for the general happiness. ${ }^{28}$ As we shall see, the principle of equal treatment unless there are good reasons for differences is one of Mill's main principles of reform, and it is present in his writings long before mid-century. One central issue in his work on political economy, then, is the extent to which considerations such as the benefits of competition constitute good reasons for inequality.

Even in this very early speech, Mill argues for a radical revision of inheritance law concerning primogeniture, under which the first-born child inherits the entire (or almost entire) estate. For Mill, it is not only that the conferring of unearned wealth on the lucky few is unfair to younger siblings and to other individuals, but also that the great concentration of wealth in just a few hands is simply contrary to general happiness:

The existence of immense fortunes, if it be good at all, must be good either as an end or as a means. If there be any person in this room who says that it is good as an end, I cannot argue with one with whom I have no principles in common, and must content myself with putting it to the Society whether they are content to assume any such end or any other end than the general happiness. I do in my conscience believe that there are persons in the higher ranks of society who think that law and government exist for the sole purpose of securing them in the possession of great masses of property. In their language, however, they are in general more moderate, and instead of holding up the preservation of large fortunes as the end, they are satisfied with representing it as an absolutely necessary means for the furtherance of a certain undefinable and undescribable end termed the good order of society. What is meant by the good order of society I never could find anybody who could tell, but one may guess the end from the sort of means which they represent as essential to its attainment. ${ }^{29}$

I do not mean to suggest Mill's views did not develop over time. ${ }^{30}$ But Mill's radical egalitarianism - in a form that makes sense of his eventual explicit support for worker cooperatives - appears early in his career.

Mill is ambivalent about neither liberty nor equality, but open-minded about the best institutions to realize both those values in different states of society. My sense is that Mill's core principles did not change all that much over time, even if his views of what institutions were justified by them did. This is, again, why interpreters should seek a synthesis from the start rather than argue that he was of two minds, or that his views shifted significantly under irrational influences. To his credit, Persky offers a synthesis, but it does not quite fully recognize that Mill's basic worries about laissez-faire capitalism and inequality appeared at a young age.

A second point I would emphasize about Mill's self-designation as a socialist is the way it follows from his having accepted (most of) the negative case made by socialists

arrested in 1823 for distributing birth control literature) and his rejection of primogeniture are two examples of youthful advocacy going well beyond the franchise and free markets.

${ }^{28}$ Mill, 'Primogeniture' (1828), CW XXVI, p. 337.

${ }^{29}$ Mill, 'Primogeniture', CW XXVI, p. 338.

${ }^{30}$ But he was remarkably consistent on many of his main concerns. In the final months of his life, for instance, Mill was still arguing for the 'abrogation of the right of primogeniture', which he regarded as 'radically wrong' ('Advice to Land Reformers' (1873), CW XXV, pp. 1228-31). 
against nineteenth-century capitalism. ${ }^{31}$ In Chapters on Socialism, he observes that despite variations in their positive proposals, 'different schools of Socialism are at one' in their criticisms of existing institutions. ${ }^{32}$ If that's right, then one could define socialism by the particular shape of those criticisms, enumerated by Mill, concerning poverty and the concentration of wealth, the lack of 'proportionality between success and merit', the lack of education for the masses, an excess of individualism and competition with 'each for himself and against all the rest', and the conversion of wage laborers 'into a kind of slaves or serfs'. ${ }^{33}$ By agreeing with these criticisms, Mill places himself on the side of the socialists. His challenge then is to work out which form of socialism to endorse given his views about the relative benefits of competition and cooperation, the good and harm of private property, the pitfalls of central planning, the value of individuality, and so forth. But his uncertainty on the positive side does not undermine either his commitment to the negative case or his appreciation of where that leaves him in the public debates.

I have suggested that Mill's explicit proposals classify him as a socialist, but perhaps the more important questions, to which I now turn, are these: did the shifts in his positive proposals make sense given his underlying principles, what were those principles, and what would those principles lead him to support today?

\section{Mill's evolutionary theory of justice}

By introducing the idea of an evolutionary theory of justice, Persky joins those commentators who hold that Mill's various proposals concerning property, cooperatives, and other matters are not inconsistent, but are rather consistent recommendations for different states of society. To borrow part of a framework from Helen McCabe, I think it essential to any proper interpretation of Mill's political philosophy to sort his reform proposals into those that are immediately available, eventually available, and only conceivably available. ${ }^{34}$ That certain forms of socialism are not feasible in the near term, and therefore not immediately available, does not imply that they are not eventually or conceivably available on Mill's view. Similarly, that Mill defends some system of private property as best among the immediately available alternatives does not entail that he regards it as best for a distant state of affairs (though he might). Our question is: what makes these different recommendations for different states of society consistent? What are the principles guiding these recommendations?

The straightforward answer is the principle of utility plus a changing assessment of what is feasible in a given state of society, encompassing 'all the greater social facts or phenomena' including public opinion, cultural considerations, economic relations, the form of government, and existing law. ${ }^{35}$ Understanding how evolving states of society make possible new institutions and social practices requires the development of good social science. With this picture in mind, Persky writes: 'The analytical heart of

\footnotetext{
${ }^{31}$ I say 'most of because even as Mill worked to articulate a more cooperative ideal, and did not think the arguments against competition 'altogether groundless', nevertheless he thought competition was beneficial all things considered (Principles of Political Economy, CW III, pp. 794-6). He also retained his scepticism of central planning (Chapters on Socialism, CW V, p. 748).

${ }^{32}$ Mill, Chapters on Socialism, CW V, p. 711.

${ }^{33}$ Mill, Chapters on Socialism, CW V, pp. 714-16.

${ }^{34}$ McCabe, 'Navigating by the North Star', p. 294.

${ }^{35}$ For Mill's definition of a 'state of society', see System of Logic, CW VIII, pp. 911-12.
} 
J. S. Mill's emerging radical utilitarian project was to use the new tools of political economy to provide a theoretical and empirical explanation of the material dynamics of progress.' $^{\text {,36 }}$

An important part of this picture, emphasized by Persky, is the need for time to allow circumstances to change: 'Time, not revolution, was to be the effective medium for material and social progress. ${ }^{37}$ Mill's evolutionary theory of justice thus entails the rejection of revolutionary socialists working for the immediate overthrow of existing institutions - 'in the hope', as he puts it, 'that out of chaos would arise a better Kosmos, and in the impatience of desperation respecting any more gradual improvement'. ${ }^{38}$ Riley calls Mill's approach a 'gradualist strategy of egalitarian reform'. ${ }^{39}$

This evolutionary approach should not lead us to conclude, however, that Mill objects to proactive efforts to reform the status quo through government intervention, legal challenges, advocacy, organizing, public pressure, and other measures consistent with social stability and freedom of discussion. Mill had an active life as a radical public reformer, challenging received laws and institutions. Nor should it obscure the fact that Mill has a general idea of the direction in which society should move.

In what, then, does progress consist for Mill? There are at least two ways of answering this question. The first is to catalogue the concrete reform proposals Mill made, the specific benefits of those reforms, and the extent to which he saw them as immediately, eventually, or only conceivably available. Much, but not all, of Persky's discussion addresses Mill's proposals in this way. To understand Mill's view of progress - and so his evolutionary theory of justice - is to enumerate the successive social and economic transitions that Mill envisions, with the understanding that these reforms would, on his view, be conducive to the general happiness. ${ }^{40}$

A second way of answering the question is to offer an account of the principles that guide his reforms, especially when general happiness is uncertain. This is a theory of reform, an account of how Mill thinks through and publicly justifies his reform proposals, short of direct appeal to the principle of utility. It helps us understand how - in the context of free discussion in an established liberal democratic society - Mill makes the public case for improvements on the status quo. ${ }^{41}$ This project is my interest here. When we go looking, we find that, in discussing concrete reforms, Mill repeatedly articulates a handful of core principles that he believes should engage the public conscience.

Persky, to his great credit, offers such an account in his chapter on luck and relational egalitarianism. On Persky's account, Mill's reform proposals are guided initially by a concern for relational or democratic equality, of the sort now commonly associated with the work of Elizabeth Anderson, but over time they come to be driven more by luck egalitarian considerations: 'For Mill, then, justice consists in unraveling over time the web of customs and institutions that produce the great inequalities - inequalities that are, in

\footnotetext{
${ }^{36}$ Persky, Political Economy of Progress, p. 21; see also p. 10.

${ }^{37}$ Persky, Political Economy of Progress, p. 21.

${ }^{38}$ Mill, Chapters on Socialism, CW V, pp. 749, 737. See Persky, Political Economy of Progress, pp. 149.

${ }^{39}$ Riley, 'J. S. Mill's Liberal Utilitarian Assessment of Capitalism versus Socialism', p. 55.

${ }^{40}$ I hasten to add that Mill always allows that our vision is limited. He does not pretend to know with any certainty what the concrete ultimate ideal would look like.

${ }^{41} \mathrm{~A}$ full theory of reform would also help us understand why the author of On Liberty does not recommend liberal democracy for all states of society. But our focus here is on the principles that shape his reform efforts within a liberal democratic society.
} 
effect, accidents of luck and birth. ${ }^{42}$ If I understand Persky's argument, the basic idea is this: throughout his career Mill was concerned with political equality and expanding civil rights, but as he moved toward socialism (again, by mid-century) he increasingly came to focus on the 'reduction of material inequality' by the 'taming of luck. ${ }^{43}$ In this way, 'Mill's framework for progressive justice, interpreted as a broad temporal move toward human development, equality, and the conquest of luck, provides a reasonable synthesis ... of the two major modern philosophic approaches to luck. ${ }^{, 44}$ For Persky, then, the main principle of reform (short of the principle of utility) itself changes over time, for he sees 'democratic equality as a transitional stage to luck egalitarianism'. ${ }^{45}$

This is a tempting theory of reform, and coheres with Persky's account of the emergence of Mill's socialism mid-century. It is important to register again the value of such an account in the first place. Only with a theory of reform in hand can we speculate in an informed way about the sorts of institutions, unforeseen by Mill, that he might have endorsed. We can then say whether institution $\mathrm{X}$ is supported by the principles that guided Mill's reform efforts, and need not fall back on his actual proposals as the only reforms he could have endorsed. I will come back to this point in the conclusion.

Although Persky's theory of reform - which lands Mill ultimately in the luck egalitarian camp - is tempting, I think it is incomplete, and mistaken as far as it goes. First, although I agree with Persky that Mill is a radical egalitarian, other reform principles need to be brought into the mix. Persky would not deny this, but it means there is much more to say about what is shaping Mill's public reform program beyond the egalitarian aims Persky mentions. I have argued elsewhere that there are five main public principles that guide Mill's reform efforts in a liberal democratic society: a principle of impartiality or equal treatment, a presumption in favor of liberty, a sufficiency or subsistence principle, a merit or effort principle, and a competence principle. ${ }^{46}$ These are not the only public principles Mill introduces to justify various reforms, but I believe they form the core of his theory of reform. In one important passage in The Subjection of Women, Mill mentions two of them:

The à priori presumption is in favour of freedom and impartiality. It is held that there should be no restraint not required by the general good, and that the law should be no respecter of persons, but should treat all alike, save where dissimilarity of treatment is required by positive reasons, either of justice or of policy. ${ }^{47}$

Here we see an expression of Mill's presumption in favor of liberty joined to his commitment to impartiality or equal treatment, in this case in the service of women's rights.

\footnotetext{
${ }^{42}$ Persky, Political Economy of Progress, p. 208.

${ }^{43}$ Persky, Political Economy of Progress, pp. 208-9.

${ }^{44}$ Persky, Political Economy of Progress, p. 209.

${ }^{45}$ Persky, Political Economy of Progress, p. 215. Despite the talk of 'transitional stages', one could read Persky as holding only that Mill's later attention to luck is laid over a foundation of relational equality. But this (1) does not do justice to the tensions between luck and relational egalitarianism and (2) fails to recognize the way Mill's attention to luck is a manifestation of his more fundamental, and abiding, relational egalitarianism.

${ }^{46}$ See Piers Norris Turner, 'John Stuart Mill on Luck and Distributive Justice', The Routledge Handbook of the Philosophy and Psychology of Luck, ed. Ian M. Church and Robert J. Hartman (New York, 2019), pp. 80-93. For an attempt to frame Mill's public reform project see my 'Social Morality in Mill', Public Reason in Political Philosophy: Classic Sources and Contemporary Commentaries, ed. Piers Norris Turner and Gerald Gaus (New York, 2017), pp. 375-400.

${ }^{47}$ Mill, The Subjection of Women (1869), CW XXI, p. 262.
} 
Much more could be said about how to weigh these principles, and a developed version of Persky's account surely could accommodate principles beyond equality. But here I just want to note this limitation of Persky's discussion for any fully elaborated interpretation of Mill's evolutionary theory of justice. In the conclusion, I will say a bit more about how his public reform principles combine to shape his views on taxes.

Second, even if we focus just on Mill's egalitarian aims, it is difficult to show that Mill shifted focus from relational egalitarianism to luck egalitarianism over time. As we have already seen in the case of primogeniture, Mill's concern with eradicating inequalities due to luck or 'accidents of birth' is on board early, in the late 1820s. Even more, his concern with relational inequality - contained in his principles of impartiality and sufficiency - is apparent in many later writings, which I pursue further in the next section.

Persky discusses at length many of Mill's reform proposals, including equal rights for women, extending the franchise, subsistence aid, heavy inheritance taxes, revising the law on primogeniture, and the provision of affordable education. Even in the cases most concerned with eradicating the effects of brute luck, however, I believe that Mill's aim is to eradicate those effects in order to establish social and political equality. Mill's egalitarian aims did not change. There was not a shift in principles so much as in his sense of which institutions were justified by them.

Consider primogeniture again. Undoubtedly, Mill objects to the practice because it rewards someone for what is a mere accident of birth. But the basic problem with this, on Mill's view, is that it is a violation of impartiality, being a broad distinction in the treatment of one person and of another, grounded solely on an accident'. ${ }^{48}$ As we saw in the passage from The Subjection of Women, the law 'should treat all alike, save where dissimilarity of treatment is required by positive reasons, either of justice or of policy'. In Utilitarianism, Mill explains that impartiality commits us to 'equality of treatment':

The equal claim of everybody to happiness in the estimation of the moralist and the legislator, involves an equal claim to all the means of happiness, except in so far as the inevitable conditions of human life, and the general interest, in which that of every individual is included, set limits to the maxim ... All persons are deemed to have a right to equality of treatment, except when some recognised social expediency requires the reverse. And hence all social inequalities which have ceased to be considered expedient, assume the character not of simple inexpediency, but of injustice. ${ }^{49}$

The impartiality or equal treatment principle is clearly violated by primogeniture. But then the fundamental problem is not the effects of brute luck itself, but the fact that rewarding luck is at odds with the establishment of impartial, equal terms of association. Inequalities might be justified by differences in merit (i.e. effort) among the parties involved, or by some important consideration of social expediency, but neither of those are in play here. The inheritance is unearned and Mill regards the concentration of great wealth in a small number of families as an obstacle to general happiness.

Much the same is true of Mill's willingness to tax inheritances heavily. Unequal treatment could be justified by merit or social expediency, but neither of those are present in the case of inheritances:

\footnotetext{
${ }^{48}$ Mill, Principles of Political Economy, CW III, p. 892.

${ }^{49}$ Mill, Utilitarianism, CW X, pp. 257-8; first emphasis added.
} 
[T] here is no injustice in taxing persons who have not acquired what they have by their own exertions, but have had it bestowed them in free gift; and there are no reasons of justice or policy against taxing enormously large inheritances more highly than smaller inheritances ... I would do so to the utmost extent to which the means could be found for imposing it without its being frustrated. ${ }^{50}$

It is not that luck is irrelevant, but rather that luck feeds into Mill's assessment of which inequalities of wealth are violations of the principle of impartiality or equal treatment, and which are not. ${ }^{51}$

Mill's egalitarian public reforms also include subsistence aid, guided by a sufficiency principle: 'The principle of securing, by a legal provision, the actual necessaries of life and health to all who cannot otherwise obtain them, we consider as now placed out of the reach of dispute by any unprejudiced person. ${ }^{52}$ This principle is also best understood in the context of relational egalitarianism. Part of the story here, Persky might note, is the taming of chance. But Mill's sufficiency principle also applies to those who have suffered from their own choices. His aim is not to remedy bad luck, but to alleviate suffering and, even in workhouses, to provide people with dignity, where 'pauperism be rendered not shameful (that is not the object). ${ }^{53}$

To move on to Mill's support for worker cooperatives, we again find that the crucial issue is not the eradication of brute luck, but rather, as Baum and others have argued, bringing democracy into the economic sphere. ${ }^{54}$ In Mill's discussion of cooperatives, he says as much:

[W]e may, through the co-operative principle, see our way to a change in society, which would combine the freedom and independence of the individual, with the moral, intellectual, and economical advantages of aggregate production; and which, without violence or spoliation, or even any sudden disturbance of existing habits and expectations, would realize, at least in the industrial department, the best aspirations of the democratic spirit, by putting an end to the division of society into the industrious and the idle, and effacing all social distinctions but those fairly earned by personal services and exertions. ${ }^{55}$

This is all the language of relational egalitarianism. In the end, we do not need to see Mill as shifting from relational egalitarianism to luck egalitarianism over time. We just need to see that addressing the effects of brute luck in many cases is a natural part of the program of relational egalitarianism. Mill's increasing willingness to identify as a 'socialist' reflects a change not in his reform principles but in the institutions and practices that he believes are required by them.

\section{The ideal of relational equality}

To bring home the centrality of relational equality to Mill's evolutionary theory of reform, one need only look to some of his most idealistic statements. As individuals

\footnotetext{
${ }^{50}$ Mill, 'The Income and Property Tax', CW V, p. 491.

${ }^{51}$ Mill, Principles of Political Economy, CW III, pp. 810-11.

${ }^{52}$ Mill, 'The Poor Laws' (1834), CW XXIII, p. 686.

${ }^{53}$ Mill, 'The Poor Laws', CW XXIII, p. 688. See also his 'French News [85]', CW XXIII, p. 673, Principles of Political Economy, CW II, p. 360, and Chapters on Socialism, CW V, pp. 713-15.

${ }^{54}$ Baum, 'J. S. Mill and Liberal Socialism', p. 114.

${ }^{55}$ Mill, Principles of Political Economy, CW III, p. 793; see also Chapters on Socialism CW V, p. 710.
} 
and institutions improve, he recognizes a possibility - one that is conceivably available, though distant and uncertain - that is thoroughly democratic, cooperative, and socially harmonious. In an 1847 letter to Arthur Helps, Mill writes:

In my estimation the art of living with others consists first \& chiefly in treating \& being treated by them as equals ... As I look upon inequality as in itself always an evil, I do not agree with any one who would use the machinery of society for the purpose of promoting it. As much inequality as necessarily arises from protecting all persons in the free use of their faculties of body \& mind \& in the enjoyment of what these can obtain for them, must be submitted to for the sake of a greater good: but I certainly see no necessity for artificially adding to it, while I see much for tempering it, impressing both on the laws \& on the usages of mankind as far as possible the contrary tendency. ${ }^{56}$

Two decades later, Mill would write:

The true virtue of human beings is fitness to live together as equals; claiming nothing for themselves but what they as freely concede to every one else; regarding command of any kind as an exceptional necessity, and in all cases a temporary one; and preferring, whenever possible, the society of those with whom leading and following can be alternate and reciprocal. ${ }^{57}$

In such a society, it becomes possible for a utilitarian like Mill to imagine degrees of social harmony and cooperation that seem fanciful to us now:

[U]tility would enjoin, first, that laws and social arrangements should place the happiness, or (as speaking practically it may be called) the interest, of every individual, as nearly as possible in harmony with the interest of the whole; and secondly, that education and opinion, which have so vast a power over human character, should so use that power as to establish in the mind of every individual an indissoluble association between his own happiness and the good of the whole; especially between his own happiness and the practice of such modes of conduct, negative and positive, as regard for the universal happiness prescribes: so that not only he may be unable to conceive the possibility of happiness to himself, consistently with conduct opposed to the general good, but also that a direct impulse to promote the general good may be in every individual one of the habitual motives of action, and the sentiments connected therewith may fill a large and prominent place in every human being's sentient existence. ${ }^{58}$

My point is not to defend these visions as entirely realistic, now or maybe ever. But they provide a sense of the direction in which Mill thought we should strive. His economic reforms echo his efforts in the social and political spheres to eradicate 'the aristocracies of colour, race, and sex' as 'injustice and tyranny'. ${ }^{59}$ These reforms are framed not as remedies for the effects of bad brute luck, but as the implications of a commitment

\footnotetext{
${ }^{56}$ Mill, Letter to Arthur Helps (1847), CW XVII, pp. 2001-2.

${ }^{57}$ Mill, The Subjection of Women, CW XXI, p. 294.

${ }^{58}$ Mill, Utilitarianism, CW X, p. 218, see also p. 233.

${ }^{59}$ Mill, Utilitarianism, CW X, p. 259.
} 
to relational equality constrained by his other principles, notably the presumption in favor of liberty and the competence principle, that guard against communism and some other forms of socialism that Mill thought would be problematic in one way or another.

\section{Conclusion: what could Mill endorse?}

I hope it is clear that I find myself in complete agreement with the overall picture of Mill on offer in Persky's book. Mill's utilitarianism is filtered through changing sets of circumstances that lead him to endorse different sets of institutions over time, and Mill's egalitarianism is at the heart of this story. But the argument of the previous two sections helps us to see that Mill's support for socialism results from the consistent application of his reform principles, notably the principle of impartiality or equal treatment, which are long-standing. These principles also challenge Persky's reluctance to comment on what Mill might say about some of the social, political, and economic options immediately available today. Persky writes:

However, it is less clear what [Mill's] attitude would be to the type of social democratic/welfare states that emerged in northern Europe after the Second World War. The promise of cooperatives was precisely that the national government would not be required to engage in substantial direct redistribution. Mill was very cautious as to the use of taxation to achieve greater income equality. He hoped workers could reach both prosperity and security without requiring the coercive force of the central government. Thus, Mill was, on the one hand, more radical than the social democrats, since he looked forward to a genuinely new mode of production. Indeed, it is his commitment to worker cooperatives that makes Mill's reform agenda a coherent whole. But on the other hand, Mill's timidity with respect to using the taxing power, must strike social democrats as an unfortunate residue of his classical liberal origins. ${ }^{60}$

This passage is somewhat surprising, because Persky's own transitional theory of reform should give us some idea of what Mill might say in the contemporary context. My own view is that Mill would be generally supportive of the social democratic states that have emerged in northern Europe and elsewhere - even if they rely on specific policies that he did not most favor in his time.

Let us consider Persky's two worries. First, he says that Mill was 'very cautious as to the use of taxation to achieve greater income equality'. We have already seen, however, that Mill was not cautious about the state imposing a very heavy inheritance tax, saying he 'would do so to the utmost extent to which the means could be found for imposing it without its being frustrated' ${ }^{61}$ Such a tax would have had a transformational effect on Victorian society, as it would today in many countries. ${ }^{62}$ Persky must be referring only to Mill's caution about taxing exertion in the form of earned income, and his apparent opposition to progressive (or 'graduated') taxes on earned income, as employed by modern social democratic states.

\footnotetext{
${ }^{60}$ Persky, Political Economy of Progress, pp. 150-1.

${ }^{61}$ Mill, 'The Income and Property Tax', CW V, p. 491.

${ }^{62}$ As observed by his friend Alexander Bain, John Stuart Mill: A Criticism with Personal Recollections (London, 1882), p. 89. Quoted in Miller, 'Mill's “Socialism”', p. 219.
} 
Taking that last point first, we should note that Mill did not entirely reject a graduated tax on earned income, because he excluded from taxation all income necessary for a basic standard of living. This tax exemption - justified by his principle of sufficiency - makes it the case that the rich are taxed a greater percentage of their income than the poor: 'It seems to me that the just claims to graduation are sufficiently satisfied by taxing only the surplus above the minimum allowance to cover necessaries. ${ }^{63}$ At a time when the great majority of people in England (and everywhere else) were living in poverty, this exemption would leave most citizens paying little or no income tax:

Our plan therefore would be, to relieve the smaller incomes from direct taxation entirely, up to the income which might be deemed fully sufficient to satisfy those physical wants of a human being which are independent of habit and convention: to keep off hunger and cold, and provide for old age, and for the ordinary chances of sickness, or other inability to work. ${ }^{64}$

It is true that Mill explicitly favored a flat tax on earned income above that basic threshold, so his nod to a graduated tax system might seem like a minor point. But if we then also include his heavy taxes on unearned income, he hardly appears reticent to tax the rich at higher levels than the poor to promote social equality.

What could Mill accept with respect to progressive taxes on earned income? Let us assume that everyone has a reasonably fair chance at a desirable existence, and thereby set aside an important set of impartiality worries that could justify a range of intrusions for Mill. Let us also assume the existence of the subsistence tax exemption. We then find his tax scheme shaped primarily by a principle of equal sacrifice (another application of the principle of impartiality): 'The just principle of taxation, I conceive to be, to impose as far as possible an equal sacrifice on all ... each should be required to give up an equal share, not of their means, but of their enjoyments. ${ }^{65}$ But as soon as this is stated, it becomes evident that Mill would be responsive to social science data about the effects of different tax rates on the well-being of different socioeconomic groups. The principle of equal sacrifice does not rule out - as a matter of principle - a progressive tax system. Today, it is commonplace to argue that a progressive tax is in fact fairer in this very respect. Mill might not have thought so in his time, but his commitment to the principle of equal sacrifice would lead him to welcome further evidence.

Mill does make a point of rewarding effort, allowing the accumulation of fortunes in a person's lifetime through one's own industry. This is an example of his merit principle, according to which effort may justify inequalities in fair circumstances, consistent with the principle of impartiality as a matter of justice. Assuming that people's effort is lawful and abides by social morality, then 'the differences of fortune arising from people's own earnings could not justly give umbrage'. ${ }^{66}$ Mill further believes that rewarding effort promotes the general welfare overall, offering a strong social expediency reason for some economic inequality. Persky is certainly right to suggest that Mill is cautious about taxation that would undermine the energy and activity needed to support a wide range of productive enterprises: 'I would make taxation bear upon

\footnotetext{
${ }^{63}$ Mill, 'The Income and Property Tax', CW V, p. 497.

${ }^{64}$ Mill, 'Errors and Truths on a Property Tax', CW XXIII, p. 553.

${ }^{65}$ Mill, 'The Income and Property Tax', CW V, p. 472; see also 'Errors and Truths on a Property Tax', CW XXIII, p. 550.

${ }^{66}$ Mill, Principles of Political Economy, CW III, p. 811.
} 
that which people acquire without exertion and talent, rather than upon that which they acquire by exertion and talent. ${ }^{67}$ But it is a leap to conclude that Mill would reject modern social democracies because they rely on heavier taxes on earned income than he envisioned in his time. Rather, what would impress Mill is that, even with higher taxes, these societies continue to reward exertion in the form of social mobility and the real possibility of significant accumulated wealth, while achieving greater levels of social, political, and economic equality than he thought available in the near term.

Persky's second worry is that the 'commitment to worker cooperatives that makes Mill's reform agenda a coherent whole' has not been realized in modern social democracies. But, again, I would argue that Mill's principles of reform are what make the whole coherent and not his particular institutional proposals. If so, I believe that Mill would welcome the development of modern social democracies in which market competition and personal liberty coexist with democratic control and greater social and economic equality. The fact that modern social democracies have come about through high taxes on earned income (rather than just high inheritance taxes), and have not relied on worker cooperatives, need not be problematic for Mill by the light of his own reform principles. Rather, I suspect he would be impressed by the degree of social, political, and economic equality that some systems have made possible without undermining general prosperity and individual liberty.

Mill envisioned a society made up of 'a well-paid and affluent body of labourers; no enormous fortunes, except what were earned and accumulated during a single lifetime; but a much larger body of persons than at present, not only exempt from the coarser toils, but with sufficient leisure, both physical and mental, from mechanical details, to cultivate freely the graces of life'. ${ }^{68}$ A fully developed account of Mill's evolutionary theory of justice will allow us to assess any new social, political, and economic possibilities from his reformist, but radical, perspective. ${ }^{69}$

\footnotetext{
${ }^{67}$ Mill, 'The Income and Property Tax', CW V. p. 493.

${ }^{68}$ Mill, Principles of Political Economy, CW III, p. 755.

${ }^{69}$ For discussion of these issues, I am grateful to Eric MacGilvray, Helen McCabe, Dale E. Miller, and Joseph Persky. I also benefited from feedback at a panel session on Persky's book at the PPE Society meeting in New Orleans in March 2019.
}

Cite this article: Turner PN (2019). Mill's Evolutionary Theory of Justice: Reflections on Persky. Utilitas 1-16. https://doi.org/10.1017/S0953820819000396 